\title{
Effect of additional alloying and heat treatment on phase composition and morphology in Al-Mg-Si-type casting alloy
}

\author{
Wpływ dodatków stopowych i obróbki cieplnej \\ na skład fazowy i morfologię stopu odlewniczego typu Al-Mg-Si
}

\begin{abstract}
The structure of permanent mold and high pressure die castings of the AlMg5Si2 Mn alloy after alloying with Li and Sc has been investigated by scanning and transmission electron microscopy, hardness and microhardness measurements, energy dispersive X-ray analysis. Three conditions, as cast, solution treated and aged, were investigated. It was shown that in as-cast state, the structure of an alloy having the nominal composition AIMg5Si2Mn consists of four phases: first - the Al based solid solution, second - the $(\mathrm{Al})+\left(\mathrm{Mg}_{2} \mathrm{Si}\right)$ eutectic, third - the primary $\mathrm{Mg}_{2} \mathrm{Si}$ crystals and fourth - the $\alpha-\mathrm{Al}(\mathrm{Mn}, \mathrm{Fe}) \mathrm{Si}$ phase. Similar phases were observed in the alloys containing Sc or Li. After two days of storing in an as-cast condition, the solid solution in all tested alloys decomposes and forms zebra-crossing shaped precipitates. TEM examinations revealed that these precipitates nucleate heterogeneously on dislocations. The solution treatment at $575.0^{\circ} \mathrm{C}$ results in spheroidization of the $\mathrm{Mg}_{2} \mathrm{Si}$ lamellas, dissolution of the precipitates and formation of $\alpha-\mathrm{Al}(\mathrm{Mn}, \mathrm{Fe}) \mathrm{Si}$ dispersoids, nucleating on the surfaces of $\mathrm{Mg}_{2} \mathrm{Si}$ lamellas. In the Sc containing alloys, the formation of $\mathrm{Al}_{3} \mathrm{Sc}$ was detected after 120 min soaking. Further heating resulted in the growth of these precipitates. Aging of the Al-Mg-Si alloys leads to an increase of hardness in all studied alloys. This effect is mainly related to precipitation strengthening, via solid solution decomposition and formation of $\beta$ "-phase. In Li-alloyed specimens, plates of $\beta \mathrm{Mg}_{2} \mathrm{Si}$ phase were observed together with small cubic-shaped $\delta^{\prime} \mathrm{Al}_{3}$ Li precipitates.
\end{abstract}

Keywords: Al-Mg-Si casting alloy, casting, alloying, heat treatment, aging, precipitation

\section{Streszczenie}

Strukturę odlewów wykonywanych w formach stałych i odlewów wysokociśnieniowych ze stopu AlMg5Si2Mn po stopowaniu Li i Sc badano za pomocą skaningowej i transmisyjnej mikroskopii elektronowej, a także wykonując pomiary twardości i mikrotwardości oraz prowadząc analizę rentgenowską z dyspersją energii. Badano trzy warianty: stan po odlaniu, odlew przesycony i starzony.

Viktoriya Boyko Associated Professor: National Technical University of Ukraine, Igor Sikorsky Kyiv Polytechnic Institute, Kiev, Ukraine; Edward Czekaj Professor, Małgorzata Warmuzek Professor: Foundry Research Institute, Krakow, Poland; Kostiantyn Mykhalenkov Professor: National Technical University of Ukraine, Igor Sikorsky Kyiv Polytechnic Institute, Kiev, Ukraine; kvmykhalenkov@gmail.com 
Wykazano, że w stanie po odlaniu struktura stopu o nominalnym składzie AIMg5Si2Mn składa się z czterech faz: pierwsza - roztwór stały na bazie Al, druga - (Al) + $\left(\mathrm{Mg}_{2} \mathrm{Si}\right)$ eutektyczna, trzecia - pierwotne kryształy $\mathrm{Mg}_{2} \mathrm{Si}$ i czwarta - $\alpha$-Al(Mn, Fe)Si. Podobne fazy zaobserwowano w stopach zawierających Sc lub Li. Po dwóch dniach przechowywania w stanie po odlaniu roztwór stały we wszystkich testowanych stopach rozkłada się i tworzy wydzielenia w kształcie przejściowym. Badania TEM ujawniły, że wytrącają one heterogenicznie jądro podczas dyslokacji. Obróbka roztworu przy $575,0^{\circ} \mathrm{C}$ powoduje sferoidyzację płytek $\mathrm{Mg}_{2} \mathrm{Si}$, rozkład wydzieleń i tworzenie dyspersoidów oraz zarodkowanie na powierzchniach płytek $\mathrm{Mg}_{2} \mathrm{Si}$. W stopie zawierającym Sc fazę $\mathrm{Al}_{3} \mathrm{Sc}$ wykryto po 120 min wygrzewania. Dalsze ogrzewanie spowodowało wzrost tych wydzieleń. Starzenie stopów Al-Mg-Si prowadzi do wzrostu twardości wszystkich badanych stopów. Efekt ten jest głównie związany z utwardzaniem wydzieleniowym na skutek rozkładu w stanie stałym i tworzenia fazy $\beta^{\prime \prime}$. W próbkach ze stopu z litem obserwowano płytki fazy $\beta-\mathrm{Mg}_{2}$ Si wraz z małymi sześciennymi wydzieleniami $\delta^{\prime}-\mathrm{Al}_{3} \mathrm{Li}$.

Słowa kluczowe: stop odlewniczy Al-Mg-Si, odlewanie, stopowanie, obróbka cieplna, starzenie, wydzielenie

\section{Introduction}

The design of new lightweight alloys for the continuous replacement of iron and steel parts is now the mainstream in energy saving and improvement of fuel efficiency in the transportation sector. In parallel to the powerful advances in aluminum wrought alloys, the search for novel high-performance casting alloys still attracts the attention of both researchers and manufacturers of aluminum casting.

Until now, the casting alloys of the Al-Si system were the most-widespread materials in foundry shops, and there are many reasons for this. These alloys are advantageous in many applications due to their high stiffness-to-weight ratio and ability to fill very thin parts of a mold cavity; what is more, it can be cast by all established casting processes. High corrosion resistance is also advantageous for this group of casting materials.

The history of another group of casting alloys based on the Al-Mg-Si system dates back to the pre-war period when, for the production of air-cooled diesel engine blocks, these alloys were employed under different names (such as Hydronalium or Hy51) [1, 2]. According to the data of Pirs and Zalar [2], an alloy containing $5.5 \mathrm{wt} . \% \mathrm{Mg}, 1.3 \mathrm{wt} . \% \mathrm{Si}$, 0.4 wt.\% Mn, and 0.4 wt.\% Ti cast into a permanent mold (PM) possessed a tensile strength of $285 \mathrm{MPa}$ and elongation of $4.8 \%$ in the heat-treated condition. Since then, however, there has been no information about either the successful nor unsuccessful application of casting alloys of this type in practice; hence, the 6XX. $X^{\text {th }}$ series in the aluminum casting alloy designation system was not very popular. Only a few publications in this field can be found in the literature $[3,4]$.

A renaissance of the Al-Mg-Si system for foundries began in 1996, when "Aluminium Rheinfelden $\mathrm{GmbH}^{\prime}$ (Germany) presented the Al-Mg-Si-type alloy to the market with a brand name of Magsimal ${ }^{\circledR}-59[5,6]$. Following the success of Magsimal, every producer of aluminum castings worldwide designed at least one casting alloy with a similar 
composition containing five to six weight percent $\mathrm{Mg}$, two percent of $\mathrm{Si}$, and manganese. In Table 1, the average composition of the recently developed Al-Mg-Si casting alloys is represented [7-12].

The advantages of the Al-Mg-Si-type casting alloys can be summarized as follows:

- Good fluidity, which provides the Al-Mg-Si casting alloys the ability to fill the thinnest sections of a mold cavity. According to Di Sabatino et al., the length of the spiral obtained by pouring the AIMg5Si2Mn alloy into a sand mold was $540 \pm 30 \mathrm{~mm}$ [12]. This is due to the presence of the $(\alpha-\mathrm{Al})+\left(\mathrm{Mg}_{2} \mathrm{Si}\right)$ eutectic.

- Good feeding behavior, because of the relatively high fraction of eutectic $(\alpha-A \mathrm{l})+$ $\left(\mathrm{Mg}_{2} \mathrm{Si}\right)$. According to [6], the eutectic volume fraction in the AlMg5Si2Mn alloy is about 30\%. Based on Thermo-Calc calculations, Otarwanna et al. [11] reported that the fraction of the eutectic is $38 \mathrm{wt} . \%$.

- High mechanical properties. For alloys subjected to high pressure die casting (HPDC), by Hielscher et al. [6] reported that, for a 3-mm-thick plate, the ultimate tensile strength (UTS) exceeds $330 \mathrm{MPa}$, a yield strength (YS) of $220 \mathrm{MPa}$, and elongation to a fracture of $18 \%$ in the as-cast condition. Similar results were obtained by Ji et al. [13]. These values are relevant to the demand of ductile alloys for automotive applications where (in some cases) riveting is applied for joining. It is worth noting that the difference in the UTS between the HPDC and permanent mold casting AlMg5Si2Mn alloy is about $100 \mathrm{MPa}$.

- Good corrosion resistance and stress corrosion cracking [14].

Table 1. Chemical composition of commercial Al-Mg-Si-Mn-type casting alloys

\begin{tabular}{|c|c|c|c|c|c|c|c|c|c|}
\hline \multirow{2}{*}{ Name } & \multirow{2}{*}{ Manufacturer } & \multirow{2}{*}{ Ref. } & \multicolumn{7}{|c|}{ Elements content, wt.\% } \\
\hline & & & Si & Mg & $\mathrm{Fe}$ & Mn & $\mathrm{Cu}$ & $\mathrm{Ti}$ & other \\
\hline Maxxalloy-59 & $\begin{array}{c}\text { Salzburger } \\
\text { Aluminium Group }\end{array}$ & [9] & $1.8-2.6$ & $5.0-6.0$ & $\begin{array}{c}0.45- \\
0.9\end{array}$ & $0.5-0.8$ & 0.08 & $\begin{array}{c}0.05- \\
0.15\end{array}$ & $\mathrm{Be}$ \\
\hline Maxxalloy-Ultra & $\begin{array}{c}\text { Salzburger } \\
\text { Aluminium Group }\end{array}$ & [10] & $2.2-3.0$ & $5.6-6.3$ & 0.2 & $0.6-0.8$ & 0.02 & $\begin{array}{c}0.05- \\
0.15\end{array}$ & $\begin{array}{c}\mathrm{Cr}, \mathrm{Be}, \\
\mathrm{RE}^{*}\end{array}$ \\
\hline Unifoundal-90 & $\begin{array}{c}\text { Salzburger } \\
\text { Aluminium Group }\end{array}$ & [9] & 2.5 & $\begin{array}{l}8.5- \\
10.5\end{array}$ & $\begin{array}{c}0.45- \\
0.9\end{array}$ & 0.55 & 0.08 & 0.15 & $\mathrm{Be}$ \\
\hline Magsimal-59 & $\begin{array}{c}\text { Aluminium } \\
\text { Rheinfelden } \mathrm{GmbH}\end{array}$ & [5] & $1.8-2.5$ & $5.0-5.8$ & 0.15 & $0.5-0.8$ & 0.05 & 0.15 & $\mathrm{Be}$ \\
\hline Magsimal-25 & $\begin{array}{c}\text { Aluminium } \\
\text { Rheinfelden } \mathrm{GmbH}\end{array}$ & [5] & 0.15 & $0.9-1.4$ & $\begin{array}{c}0.10- \\
0.40\end{array}$ & $0.9-1.4$ & - & 0.2 & Co \\
\hline Aural 11 & Rio Tinto Alcan & [7] & $1.8-2.2$ & $4.0-5.0$ & $\begin{array}{c}0.15- \\
0.22\end{array}$ & $0.5-0.6$ & 0.03 & $\begin{array}{c}0.04- \\
0.08\end{array}$ & - \\
\hline AIMgSiMn & Hydro Aluminium & [8] & $0.2-2.0$ & $1.0-5.0$ & - & $0.7-1.3$ & - & - & - \\
\hline
\end{tabular}

* RE - rare earth metals 
All of the above-mentioned advantages are usually attributed to the HPDC AlMg5Si2Mn alloy in the as-cast condition, whereas the effect of heat treatment on the structure, precipitation, and mechanical properties is considered in a limited number of publications [14-16]. Hu et al. [14] reported that the UTS of the HPDC AIMg5Si2Mn alloy in the as-cast condition is $324 \mathrm{MPa}$, and the YS is $183 \mathrm{MPa}$. For the alloy aged at $250^{\circ} \mathrm{C}$ directly after casting, the UTS increased to $369 \mathrm{MPa}$ and the YS - to $236 \mathrm{MPa}$. Elongation remained basically at the same level $(8.31 \%$ in the as-cast condition, and $8.47 \%$ after age treatment). Comparative studies of the AIMg5Si2Mn alloy cast into a permanent mold (PM) and HPDC [14] showed that the UTS of the permanent mold casting was $160 \mathrm{MPa}$ in the as-cast condition, whereas the HPDC alloy showed a UTS of $314 \mathrm{MPa}$. By subjecting the AIMg5Si2Mn alloy to HPDC, higher levels of YS and elongation can also be achieved.

The difference of the UTS, YS, and elongation between the PM and HPDC alloys is usually attributed to the following factors:

- smaller size of the $\alpha$-Al grains of the HPDC alloy [14] than that of the PM,

- changes of the eutectic morphology from plate-like to fibrous,

- formation of large shrinkage pores in the PM alloy,

- detrimental effect of Fe-rich intermetallic particles, which exhibit two different morphologies in the PM alloy in contrast to one for the HPDC alloy.

The observations of Petkov et al. $[15,16]$ revealed that the highest level of mechanical properties of the PM AIMg5Si2Mn alloy could be achieved after solution treatment at $570^{\circ} \mathrm{C}$ for 8 hours, water quenching, and artificial aging at $240^{\circ} \mathrm{C}$ for 8 hours. After heat treatment, the UTS of the alloy increased from $172 \mathrm{MPa}$ in the as-cast condition to $226 \mathrm{MPa}$, and the YS - from $85 \mathrm{MPa}$ to $173 \mathrm{MPa}$, respectively. The authors attribute the improvement of strength to the formation of $\beta^{\prime \prime}$ or $\beta^{\prime}$ precipitates. However, such levels of the UTS and YS are much lower than that for the commercial A356 T6 alloy cast into a permanent mold.

From this short review, one can conclude that the mechanical properties of the HPDC AIMg5Si2Mn alloy are greater than those of the PM alloy. However, the origins of such high mechanical properties of AIMg5Si2Mn-type alloys subjected to HPDC have yet to be sufficiently explained. Heat treatment cannot improve properties up to the level of well-established casting alloys like A319 or A356.

Several attempts have been made to increase the mechanical properties of Al-MgSi-Mn-type casting alloys by additional alloying. It was reported by Ji et al. $[17,18]$ that a $\mathrm{Cu}$ addition can slightly increase the YS in the as-cast condition, with a significant reduction of ductility. SAG reported about the design of a special alloy containing $\mathrm{Cr}$, Be, and rare-earth elements that offers maximum strength and ductile yield properties already after casting, making heat treatment unnecessary (see Tab. 1). Eigenfeld et al. [18] reported that the AIMg3Si1 $\left(\mathrm{Sc}+\mathrm{Zr}\right.$ ) alloy is suitable for application above $250^{\circ} \mathrm{C}$, and its mechanical properties are excellent. 
Since 1920, the addition of Li to Al-based alloys has been considered one of the most-effective methods for reducing the density and improving the specific strength and stiffness-to-weight ratio [19]. The addition of Li to Al can provide the greatest reduction in density and largest increase in the elastic modulus of any known alloying elements. The ability of the Li addition to improve the properties of Al-based alloys is attributed to the low density of $\mathrm{Li}\left(0.534 \mathrm{~g} / \mathrm{cm}^{3}\right)$ and formation of $\delta$ - $\mathrm{Al}_{3} \mathrm{Li}$ precipitates during artificial aging.

Now, the third generation of Al-Li wrought alloys are undergoing implementation to the production of different aerospace constructions. However, there has been no single Li-containing casting alloy that had been designed yet. Sauermann et al. [20] showed that the commercial Al-Mg-Li alloy (A1420) can be subjected to the Rheo Container Process. By using this technology along with T6 heat treatment, it is possible to achieve $383 \mathrm{MPa}$ UTS, $235 \mathrm{MPa}$ YS, and 7.5\% elongation, thus specifying that the Li-containing alloy has the potential to be cast.

In this article, the as-cast condition of the AIMg5Si2Mn alloy after permanent mold casting and high pressure die casting in addition to adding $\mathrm{Sc}$ or Li is characterized comprehensively regarding the structure, element distribution, and precipitates formed in the as-cast state as well as after heat treatment.

\section{Experimental}

The alloys were melted in clay graphite crucibles in an electric resistance furnace. For each alloy series, individual crucibles were used to avoid contamination from different alloying elements.

As a starting material, high-purity aluminum (A99.997) was used. The alloying elements were added via master alloys; namely, AlSi25, AlMn26, AlMg50, AlSc2, AlZr10, and AlLi5 master alloys. Both the aluminum and master alloys were cut into small pieces and weighed to the appropriate proportions before charging. During the experiments, each element was weighted to a specified ratio (with an additional amount for burning loss during melting). The batch weight was about $250 \mathrm{~g}$ as a reference rate for all melts.

First, aluminum 99.8 purity was melted and maintained at $720.0^{\circ} \mathrm{C}$; then, the AISi25 and AIMn26 master alloys were added into the melt and stirred using a graphite rod. After complete dissolution of the master alloys, the melt was heated up again to $720.0 \pm 5^{\circ} \mathrm{C}$, and its surface was covered by flux powder. As a flux powder, carnallite $\left(\mathrm{Mg}\left[\mathrm{H}_{2} \mathrm{O}\right]_{6} \mathrm{KCl}_{3}\right)$ was used. Prior to the addition, it was dried for 24 hours at $250.0^{\circ} \mathrm{C}$. Between different castings, the flux powder was stored in the preheated furnace to avoid its interaction with air and moisturizing. Mg and/or Li was made then added in the following manner: pieces of $\mathrm{Mg}$ - and $\mathrm{Li}$-containing master alloys were wrapped in aluminum foil and added in small increments by plunging them under the melt surface using a titanium instrument. Prior to the addition of $\mathrm{Li}$, the melt surface was flushed by dry argon 
using a specially designed lance. Flushing protects the melt surface from interaction with the environment and decreases the probability of $\mathrm{Li}$ and/or $\mathrm{Mg}$ being oxidized.

After the addition of $\mathrm{Mg}$ and $\mathrm{Li}$, argon fluxing was used to remove the non-metallic impurities and soluble gases from the melt. Fluxing time was 10 minutes and kept constant for all melts. After fluxing, the melt surface was skimmed to remove dross; after reaching a temperature of $700.0^{\circ} \mathrm{C}$, the alloys were cast into a steel mold. The mold temperature was $25.0^{\circ} \mathrm{C}$ for all casting (to produce similar cooling conditions for all alloys). Preliminary tests showed that such conditions result in a cooling rate of $2 \mathrm{~K} \cdot \mathrm{s}^{-1}$ prior to solidification. The chemical compositions of the alloys are provided in Table 2.

The obtained ingots were cut into two halves. One was used for macroetching and the other for cutting the specimens for heat treatment and metallographic examinations.

For comparison, the commercial AlMg5Si2Mn alloy in the form of a 3-mm-thick high-pressure die-casting plate (defined as HPDC) was subjected to the research program. The cast plate was supplied by "Aluminium Rheinfelden GmbH" (Germany).

Two types of heat treatment were applied. The first was a solution treatment, which was conducted in an electrical resistance furnace. Before treatment, the furnace was heated up to the solution-treatment temperature of $570^{\circ} \mathrm{C}$ and kept for 12 hours at this temperature. Then, the specimens were positioned in the central part of the preheated furnace to ensure equal heating rates and temperature distribution around the specimens. The temperature was controlled by a K-type thermocouple placed directly at the surface of the specimens. Times from 20 minutes up to 24 hours were used for the solution-treatment studies. The time for reaching the solution-treatment temperature was 10-15 minutes and is excluded from the presented times. After the solution treatment, the specimens were quenched in $25.0^{\circ} \mathrm{C}$ water.

Table 2. Chemical composition of alloys under investigation

\begin{tabular}{|l|c|c|c|c|c|c|c|c|}
\hline \multirow{2}{*}{ Alloy } & \multicolumn{7}{|c|}{ Elements content, wt.\% (Al-balance) } \\
\cline { 2 - 10 } & $\mathbf{M g}$ & $\mathbf{S i}$ & $\mathbf{M n}$ & $\mathbf{C u}$ & $\mathbf{L i}$ & $\mathbf{T i}$ & $\mathbf{S c}$ & $\mathbf{F e}$ \\
\hline Base alloy (BA) & 5.32 & 2.12 & 0.58 & 0.001 & - & 0.02 & - & 0.03 \\
\hline Sc addition (Sc) & 5.28 & 2.08 & 0.61 & 0.001 & - & 0.01 & 0.7 & 0.03 \\
\hline Li addition (Li) & 5.30 & 2.10 & 0.59 & 0.001 & 1.00 & 0.01 & - & 0.03 \\
\hline $\begin{array}{l}\text { HPDC plate } \\
\text { (HPDC) }\end{array}$ & 5.47 & 2.20 & 0.69 & 0.02 & - & 0.1 & $\begin{array}{c}0.004 \\
(\mathrm{Be})\end{array}$ & 0.12 \\
\hline
\end{tabular}

The second type of heat treatment was T6, which combines a solution treatment (at $570 \pm 3^{\circ} \mathrm{C}$ ), quenching, and artificial aging. Artificial aging was conducted in a forced circulation air furnace at $175.0 \pm 3^{\circ} \mathrm{C}$ for various times. The specimens were taken out of the furnace and cooled in still air after artificial aging. 
The specimens for the metallographic investigations were prepared using standard metallographic procedures. A Zeiss Axioskop optical microscope with an MR MC80 digital camera with AxioVision Rel. 4.7 software was used for the metallographic analysis. The SEM's used in this work are Zeiss EVO and ULTRA. All microscopes were equipped with Energy Dispersive Spectrometry (EDX) systems. The quantitative SEM/EDX analysis was performed under 5 and $10 \mathrm{kV}$ accelerating voltage.

The thin foil preparation for transmission electron microscopy (TEM) studies were carried out in a twin jet Struers Tenupol 3 electropolishing machine. Disks with a diameter of $3 \mathrm{~mm}$ and thickness of about $150 \mu \mathrm{m}$ were electropolished using an electrolyte with $70 \%$ methanol, $20 \%$ glycerol, and $10 \%$ perchloric acid kept at $-27.0^{\circ} \mathrm{C}$ and at a voltage of $20 \mathrm{~V}$.

All TEM investigations were carried out using a Philips CM 30 TEM operated at $250 \mathrm{kV}$ accelerating voltage and equipped with an Energy Dispersive Spectrometry (EDX) system (Noran System Six EDS, Thermo Scientific). Bright field (BF) images were used for observing the morphology of the solid solution grains, intermetallics, and precipitates. Element concentrations were measured using spot sizes of $4-10 \mathrm{~nm}$. The given concentrations are averaged over measurements in ten individual grains for HPDC casting or dendrite arms in the case of specimens that are laboratory melted and cast into a permanent mold.

Microhardness tests were carried out on polished non-etched specimens on a Duramin-2 microhardness tester. These Vickers microhardness measurements were performed on the primary $\alpha$-Al grains for the HPDC alloy or dendrite arms for the permanent mold casting using a $0.05 \mathrm{Kgf}$ load for 10 seconds. Ten indentations are performed on each sample and then averaged.

\section{Results}

\section{Microstructure and phase composition in as-cast condition}

The structures of the base alloy (BA) is shown in Figures $1 \mathrm{a}$ and $1 \mathrm{~b}$. The alloy exhibits a relatively coarse grain structure and four phase constituents can be clearly distinguished in the Al matrix; namely:

- dendrite arms of the $\alpha$-Al solid solution (denoted as $\alpha$-Al, Fig. 1a),

$-(\alpha-\mathrm{Al})+\left(\mathrm{Mg}_{2} \mathrm{Si}\right)$ eutectic (denoted as $(\alpha-\mathrm{Al})+\left(\mathrm{Mg}_{2} \mathrm{Si}\right)$, Figs. $1 \mathrm{a}$ and $\left.1 \mathrm{c}\right)$,

- $\mathrm{Mg}_{2} \mathrm{Si}$ primary crystals (denoted as $\mathrm{Mg}_{2} \mathrm{Si}_{\mathrm{p}}$, Fig. $1 \mathrm{~d}$ ),

- Mn-containing phase (denoted as Mn-containing phase, Fig. 1b).

The preferential morphology of the $\alpha-\mathrm{Al}$ in the BA alloy is dendrite with long primary arms. The $(\alpha-\mathrm{Al})+\left(\mathrm{Mg}_{2} \mathrm{Si}\right)$ eutectic has a lamellar morphology, where long $\mathrm{Mg}_{2} \mathrm{Si}$ plates (see Fig. 1c) alternate with the $\alpha$-Al. The spacing between $\mathrm{Mg}_{2} \mathrm{Si}$ lamellas varies 
within a range of $0.77-0.92 \mu \mathrm{m}$. The primary $\mathrm{Mg}_{2} \mathrm{Si}$ crystals have a regular polyhedral shape and are situated in the centers of the eutectic colonies (Fig. 1d). In the field of the $\alpha-\mathrm{Al}$, an additional phase was observed. It appears in the form of bright irregular shaped particles (denoted as the Mn-containing phase, Fig. 1b).

a)

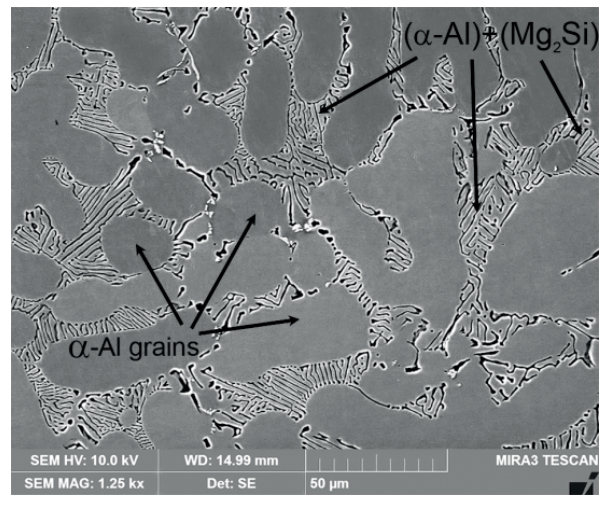

c)

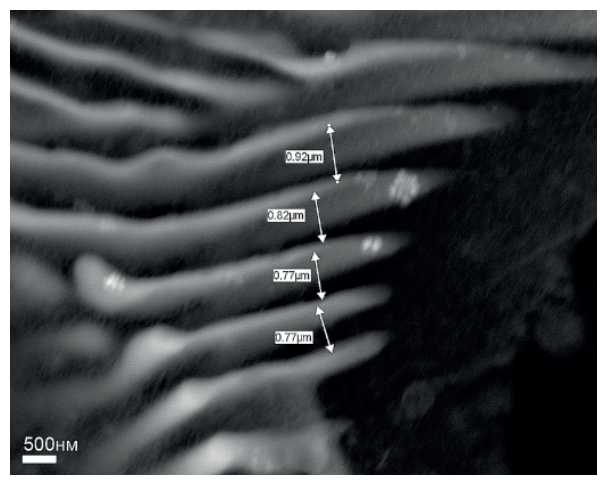

b)

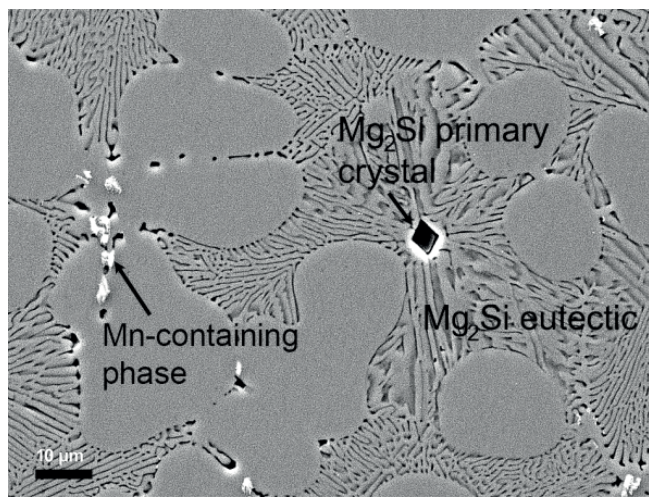

d)

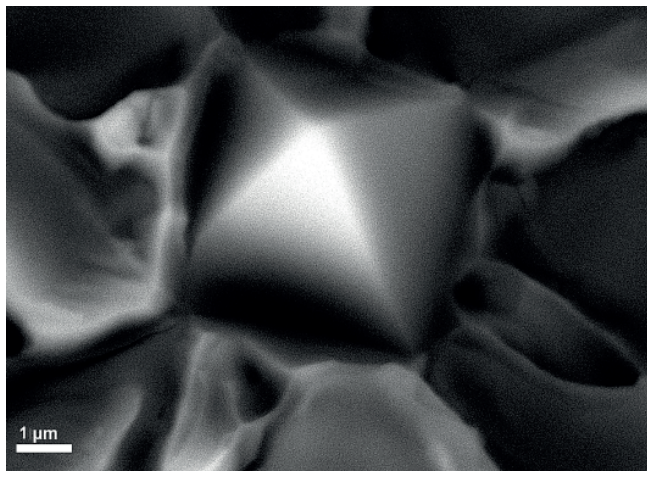

Fig. 1. Microstructure of base alloy (BA) (SEM observations): a) morphology of $\alpha$-Al grains and $(\alpha-A l)+\left(\mathrm{Mg}_{2} \mathrm{Si}\right)$ in base alloy (BA); b) morphology of primary $\mathrm{Mg}_{2} \mathrm{Si}$ crystals and Mn-containing phase in base alloy (BA); c) plate-like morphology of $\mathrm{Mg}_{2} \mathrm{Si}$ lamellas after deep etching; d) morphology of primary $\mathrm{Mg}_{2} \mathrm{Si}$ crystal situated in center of eutectic colony

For the HPDC alloy, the globular morphology of the $\alpha$-Al was observed along with the fine lamellar morphology of the $(\alpha-\mathrm{Al})+\left(\mathrm{Mg}_{2} \mathrm{Si}\right)$ eutectic. TEM EDX analysis confirms that the lamellar microstructure of the eutectic consists of the $\alpha-A l$ and $\mathrm{Mg}_{2} \mathrm{Si}$ phases (see Figs. 2a and 2b). 
In Figures $2 c$ and $2 d$, the microstructures of the alloys containing $S c$ and Li are shown. The microstructure of the Li-containing alloy is similar to that of the BA and consists of four phases (denoted as the $\alpha$-Al solid solution, $\mathrm{Al}+\mathrm{Mg}_{2} \mathrm{Si}$ eutectic, primary $\mathrm{Mg}_{2} \mathrm{Si}$ crystals, and $\mathrm{Mn}$-containing phase). The same phase constituents were detected in the Sc alloy; however, the morphology of the $\alpha$-Al grains significantly differs from the BA alloy. As can be seen in Figure 2c, the $\alpha$-Al grains have a globular morphology, and their average size is within a range of $30-50 \mu \mathrm{m}$ (which is close to the HPDC alloy). In addition to these phases, a cubic-shaped phase was detected in the Sc alloy. This phase is situated in the centers of the $\alpha$-Al grains (see Fig. 2c). The position of the particles clearly indicates that they acted as the nucleation particles for the $\alpha$-Al grains. By TEM EDX measurements, it was found that these particles are the $\mathrm{Al}_{3} \mathrm{Sc}$ phase, thus indicating the strong potential of the $S c$ addition to refine the grains of the $\alpha$-Al solid solution due to the formation of the primary $\mathrm{Al}_{3} \mathrm{Sc}$ particles.

a)

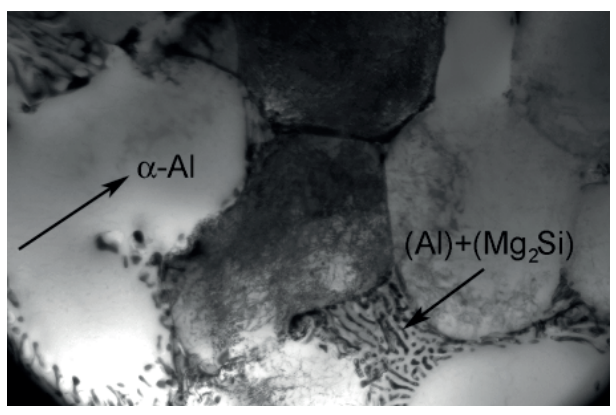

c)

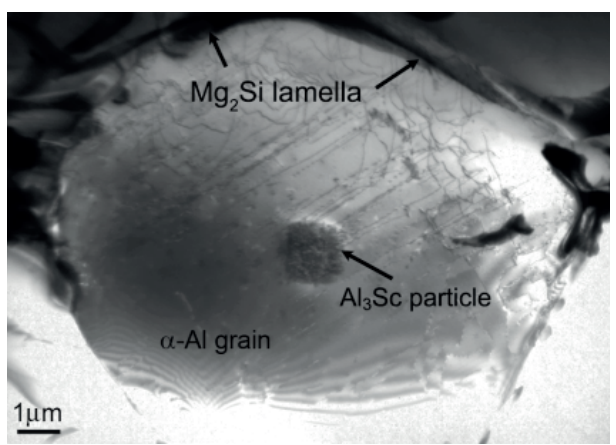

b)

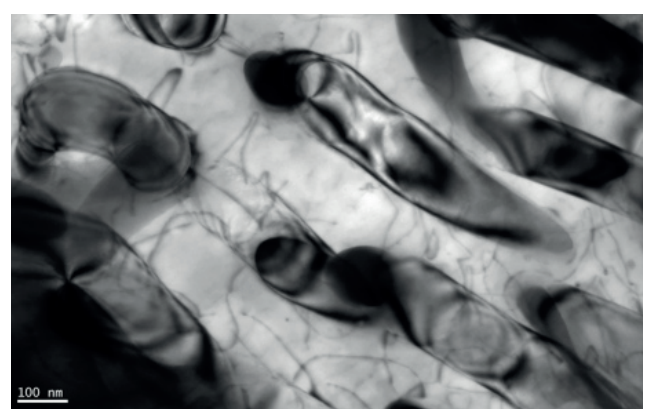

d)

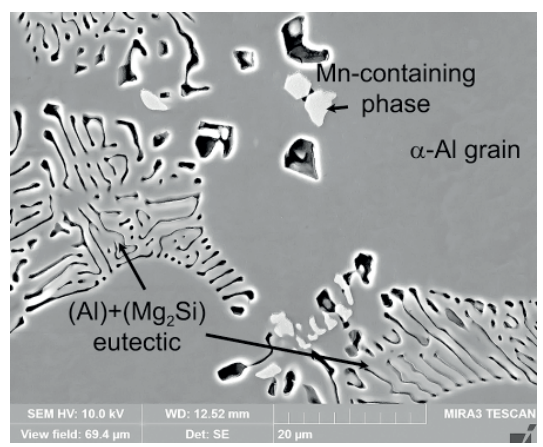

Fig. 2. Microstructure of alloys: subjected to HPDC (a, b); containing Sc (c); Li additions (d): a) bright field image of $\alpha$-Al graines observed in AIMg5Si2Mn HPDC alloy; b) bright field image of $\mathrm{Mg}_{2} \mathrm{Si}$ lamellas in AIMgSSi2Mn HPDC alloy; c) bright field image of $\alpha$-Al grain in Sc alloy cast into permanent mold; $d$ ) microstructure of Li alloy cast into permanent mold (SEM image) 
According to the invariant equilibrium $\mathrm{L} \rightleftharpoons(\mathrm{Al})+\left(\mathrm{Mg}_{2} \mathrm{Si}\right)$ at a eutectic temperature of $594^{\circ} \mathrm{C}[21,22]$, liquid phase L contains $9.82 \mathrm{wt} . \% \mathrm{Mg}, 4.10 \mathrm{wt}$ \% Si, and $86.08 \mathrm{wt} . \% \mathrm{Al}$. Simultaneously, at room temperature the Al-based solid solution ( $\alpha$-Al) contains $2.44 \mathrm{wt} . \% \mathrm{Mg}$, $97.35 \mathrm{wt} . \% \mathrm{Al}$, and $0.21 \mathrm{wt} . \% \mathrm{Si}$. In the present work, the composition of the phases was measured by EDX analysis using the SEM and TEM microscopes.

The $\alpha$-Al of BA alloy nearly exclusively contains Mg (see Tab. 3). Its content in the solid solution measured in SEM using $10 \mathrm{kV}$ acceleration voltage varies within a range of 2.2-2.6 wt.\% (which slightly differs from that measured by TEM). TEM/EDX measurements showed the Mg content in the $\alpha$-Al are within a range of 2.3-2.5 wt.\%. For the alloys under investigation, the Mg content in the solid solution measured by SEM/EDX is slightly higher than that measured by TEM. Because of the lower spatial resolution of the EDX measurement in the SEM, this could be due to the Mg-rich surrounding of the $\alpha$-matrix and presence of $\mathrm{Mg}$-containing compounds lying beneath the specimen surface (which could also contaminate the spectra).

Table 3. Average chemical composition of $\alpha-A$ I in BA and HPDC alloys measured in SEM and TEM

\begin{tabular}{|c|c|c|c|c|}
\hline \multirow{2}{*}{ Element } & \multicolumn{4}{|c|}{ Alloy } \\
\cline { 2 - 5 } & \multicolumn{3}{|c|}{ BA } & HPDC \\
\cline { 2 - 5 } & SEM, wt.\% & TEM, wt.\% & SEMt.\% & TEM, wt.\% \\
\hline $\mathrm{Mg}$ & 2.63 & 2.24 & 2.76 & 2.44 \\
\hline $\mathrm{Al}$ & 96.52 & 97.07 & 96.55 & 97.71 \\
\hline $\mathrm{Si}$ & 0.30 & - & 0.30 & - \\
\hline $\mathrm{Mn}$ & 0.41 & 0.49 & 0.51 & 0.53 \\
\hline
\end{tabular}

The Si content in the BA alloy measured by TEM/EDX was at the limit of detection. The small Si content measured in the case of SEM/EDX analysis obviously originated from the surrounding $\mathrm{Mg}_{2} \mathrm{Si}$ lamellas or from those lying beneath the surface.

The close values of the Mg and Mn content in the $\alpha$-Al detected for the BA and HPDC alloys specifies that an increase in the cooling rate cannot shift the saturation of the $\alpha$-Al toward the higher levels of foreign atoms. It was also observed that, for all alloys, the Mg content in the solid solution measured by SEM/EDX is higher than that measured by TEM. Because of the lower spatial resolution of the EDX measurement in the SEM, this could be due to the Mg-rich surrounding of the $\alpha$-Al.

The average element content in the $\mathrm{Mg}_{2} \mathrm{Si}$ eutectic lamella is as follows: $\mathrm{Mg}-$ $18.30 \mathrm{wt} . \% ; \mathrm{Si}-34.10 \mathrm{wt} . \% ; \mathrm{Al}-18.70 \mathrm{wt} . \%$. The spectra showed a relatively high oxygen content of 28.10 wt.\%, which makes identifying the composition difficult. In various EDX measurements, the oxygen content in the spectra was within a range of $20.00-40.00 \mathrm{wt} . \%$. Even when oxide polishing suspension was not applied in the final polishing stage, the oxygen content of the lamellas remains at the high level. EDX measurements in TEM show 
similar results, with an oxygen content of about $10.00 \mathrm{wt} . \%$. This result implies that the $\mathrm{Mg}$ and Si containing intermetallics in the matrix of each alloy exhibit a strong tendency for oxidizing. The lowest oxygen concentration was measured in TEM EDX when the lamella was covered by a thin layer of the Al matrix. In this case, the quantification gives a lamella composition close to the stoichiometric composition of $\mathrm{Mg}_{2} \mathrm{Si}$. The measured composition was as follows: $\mathrm{Mg}-64.56$ at. $\% ; \mathrm{Si}-31.17$ at.\%.

The Mn content measured by both methods is within a range of 0.35 to $0.55 \mathrm{wt} . \%$, which is almost equal to the $\mathrm{Mn}$ addition to all alloys under investigation. It is distributed nearly homogeneously inside the dendrite arms of the $\alpha$-Al and globular grains for the HPDC alloy. The morphology of the primary Mn-containing phase observed in the BA alloy is shown in Figure 1b.Its chemical composition is as follows: $\mathrm{Al}-74.45$ at.\%; $\mathrm{Mn}-15.78 \mathrm{at} . \%$; $\mathrm{Si}-4.73$ at.\%; Fe -0.04 at.\%. This phase can be identified as $\alpha-\mathrm{Al}(\mathrm{Mn}, \mathrm{Fe}) \mathrm{Si}$, which is often observed in commercial aluminum casting alloys after $\mathrm{Mn}$ alloying.

EDX analysis of the Li alloy performed along the $\alpha$-Al dendrite arms showed that the $\mathrm{Mg}$ and $\mathrm{Mn}$ content is nearly the same as in the BA alloy. Mg distribution across the dendrite arms of the solid solution measured using TEM/EDX is shown in Figure 3. One can see that in presence of $1.00 \mathrm{wt} . \%$ Li provides less homogeneous $\mathrm{Mg}$ distribution in the $\alpha$-Al as compared to the BA alloy.

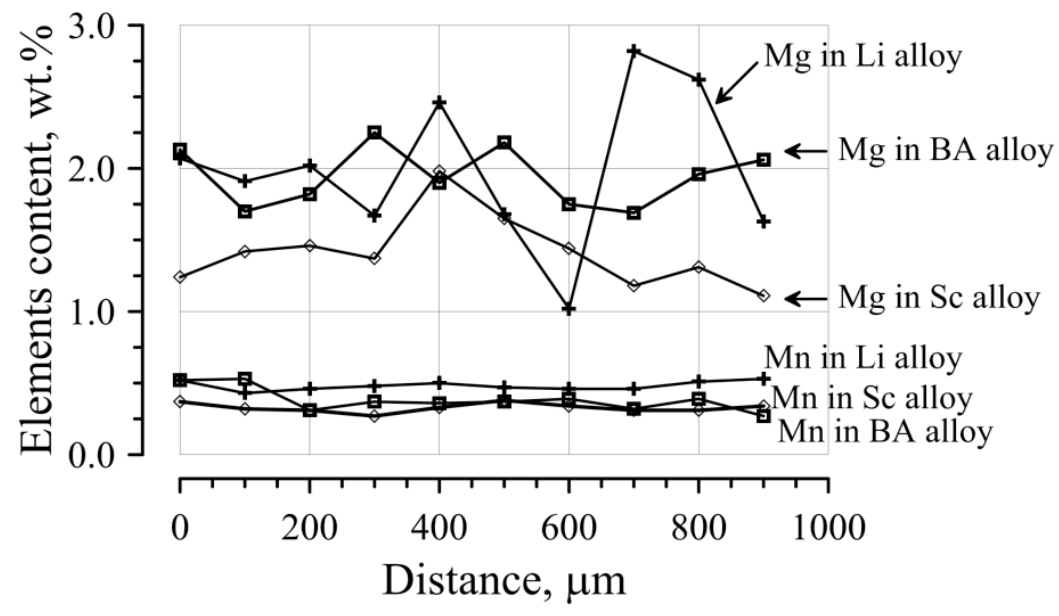

Fig. 3. $\mathrm{Mg}$ and $\mathrm{Mn}$ distribution across dendrite arms in SC, Li, and BA alloys (TEM/EDX)

The average $\mathrm{Mn}$ content in the $\mathrm{Li}$ in the solid solution is about $0.35 \mathrm{wt} . \%$ and at the same level for the BA alloy. The Si content in the $\alpha$-Al for the Li and BA is below the limit of detection.

For the Sc alloy, no pronounced refinement of the phase constituents was observed (except for $\alpha$-Al grains). However, EDX analysis of the aluminum matrix shows 
a significant reduction in the average $\mathrm{Mg}$ content in the $\alpha-\mathrm{Al}$ (dropping to $1.40 \mathrm{wt} . \%$ ). The Mn content remains the same and is about $0.40 \mathrm{wt} . \%$. The average Sc content in the matrix was measured to be $0.34 \mathrm{wt} . \%$.

Summarizing the obtained results, one can state that neither the Li or Sc changes the phase equilibrium in the Al-Mg-Si system within the investigated limit; they merely produce an additional saturation of the solid solution. This could enhance the mechanical properties of the alloys by solid solution strengthening. Indeed, the hardness and microhardness tests of the as-cast alloys show that $\mathrm{Li}$ - and Sc-containing alloys have the highest values of $\mathrm{HB}$ and $\mathrm{HV}_{0.05}$ as compared to the BA and HPDC alloys (see Fig. 4).

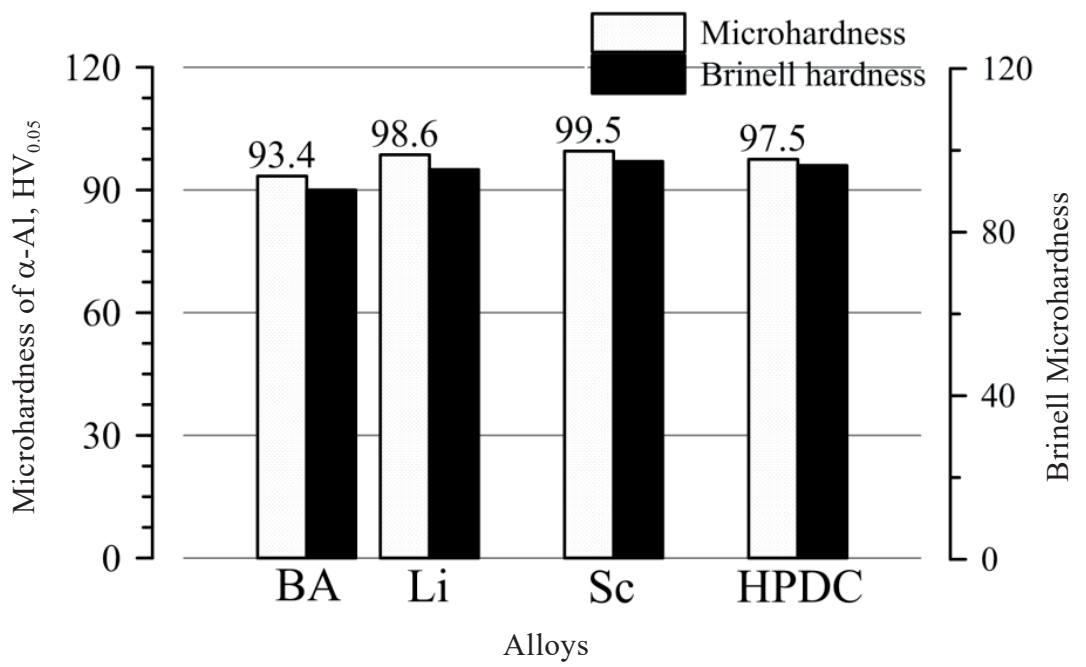

Fig. 4. Brinell hardness and microhardness of Al-Mg-Si casting alloys in as-cast condition

The most-interesting results were obtained during the TEM examinations of the $\alpha$-Al grains in all samples. The $\alpha$-Al grains contain plate-like precipitates. These plates are elongated along a certain direction and are arranged parallel to each other, resulting in a pattern like a zebra crossing (as can be seen in Figure 5). On one side of this pattern, a carved black line is visible, which could be identified as a dislocation. This generalization is true for all of the studied alloys. Detailed investigations of these precipitates allowed us to reveal their features:

- composition of precipitates is very close to stoichiometric $\mathrm{Mg}_{2} \mathrm{Si}$ compound,

- for all specimens, precipitates are aligned along dislocations,

- precipitation density is much higher for the HPDC alloy than for the PM alloys,

- precipitates are only distributed in the field of the solid solution; precipitates were not detected between the eutectic lamellas. 
a)

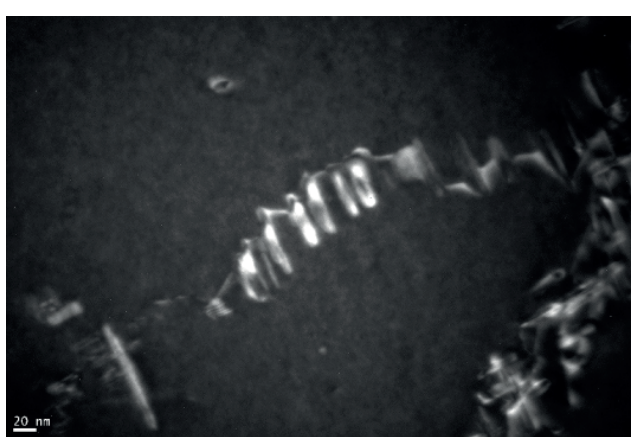

b)

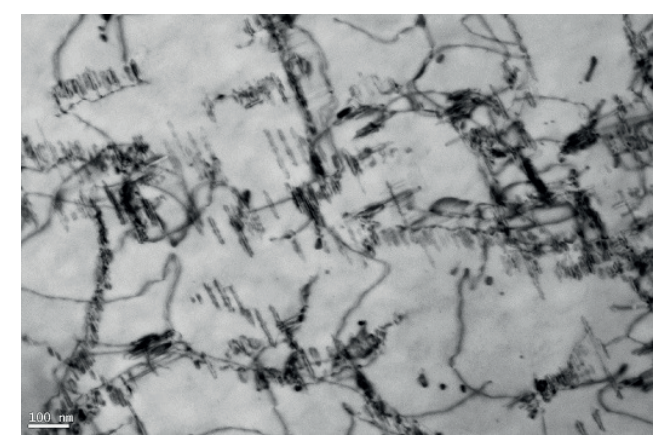

Fig. 5. Dark and bright field images of zebra crossing-type precipitates observed in all studied alloys: a) dark field image of precipitates observed in BA alloy; b) bright field image of precipitates in HPDC alloy

This zebra crossing structure is an effect of natural aging. The TEM investigation of the BA and Li alloys performed three hours after casting showed that there are no precipitates inside the $\alpha$-Al matrix. They appear in the alloys examined after three days of aging at room temperature. Their growth could sometimes be directly observed in the TEM when the TEM foil heated up by inelastic scattering. The average size of the precipitates was within a range of $80-120 \mathrm{~nm}$. The alloy composition has no effect on the precipitate size.

From this observation together with the alignment of precipitates along the dislocations, it can be concluded that the main mechanism of their formation is the heterogeneous nucleation in the stress field of dislocations during the natural aging of the alloys. The high dislocation density in the HPDC sample originated from differences in the thermal expansion of $\alpha-\mathrm{Al}$ and $\mathrm{Mg}_{2}$ Si together with the pressure applied during HPDC, which provided more nucleation sites for the precipitates. Thus, the precipitation density is much higher for the HPDC alloy than for the BA, Sc, and Li alloys; the presence of these precipitates resulted in the high mechanical properties of the AIMg5Si2Mn HPDC alloys in the as-cast state. The confirmation of this was found after hardness measurements of the HPDC and BA samples, where the Brinell hardness of the BA sample $(H B=90)$ was lower than in the HPDC sample $(\mathrm{HB}=96)$. When no pressure is applied (as during mold filling and solidification), the precipitate's density is much lower. So, pressure obviously plays a more-important role for dislocation generation than thermal stress. Also, it has to be mentioned that the different cooling rates did not influence the growth and size of these precipitates.

An enlarged view of the precipitates in the Sc is shown in Figure 6a. The schematic presentation of zebra crossing structure is given in Figure $6 \mathrm{~b}$. Tilting the specimen to different zone axes and using different reflections for diffraction contrast allowed us to 
reconstruct the geometry of this structure as well as the nature of the dislocation. The plates are lying in (100) planes, and their long axis is [010]. The dislocation has a Burgers vector of $\vec{b}= \pm \frac{1}{2}[10 \overline{1}]$. It connects the plates on the right side in a curved line, which can be described by the average direction [ $\overline{6} \overline{2} \overline{8}]$ or simplified [101]. So, the plates are not lying in one (100) plane but are shifted in the [100] and [001] direction. The dislocation forms a loop around each precipitate. Along the long side of the precipitate, the dislocation segment has a line vector of [010] and a Burgers vector of $\vec{b}= \pm \frac{1}{2}[10 \overline{1}]$; i.e., it is an edge dislocation.

a)

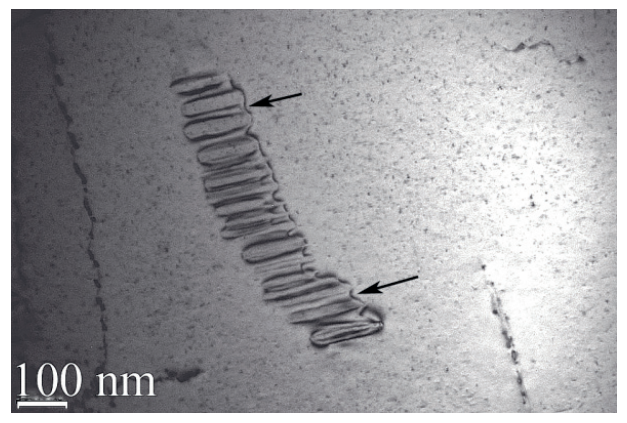

b)

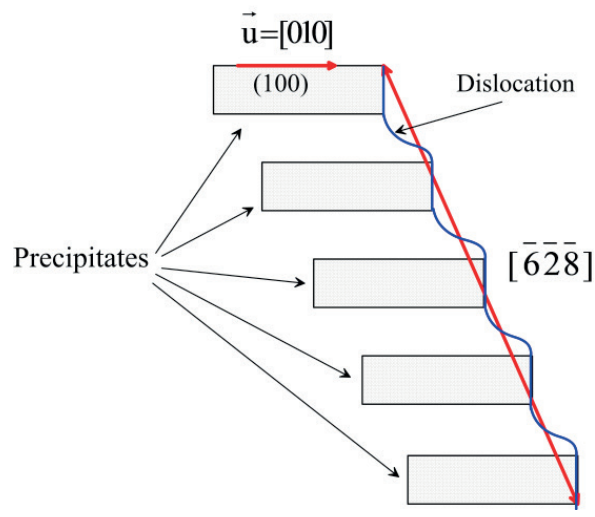

Fig. 6. Enlarged view of precipitates in Sc alloy: a) dislocation marked by arrows; b) schematic presentation of precipitates and dislocation

\section{Microstructure and phase composition changes during solution treatment}

The solution treatment temperature for the alloys under consideration was chosen to be $575.0^{\circ} \mathrm{C}$. This is $20.0^{\circ} \mathrm{C}$ lower than the eutectic melting point for Al-Mg-Si. The change of the microhardness during the solution treatment is illustrated in Figure $7 . \mathrm{HV}_{0.05}$ starts to decrease rapidly after the beginning of the solution treatment and stabilizes after 20-40 minutes.

Because the indentations were placed in the $\alpha$-Al, these results indicate the softening of the matrix; therefore, the measured effect is most likely due to the dissolution of the precipitates of the $\beta$ "-phase (formed during natural aging), as was shown by Boyko et al. [23]. In addition, during the time period between 600 and 1200 minutes, the HV gradually increased but did not reach the level of that in the as-cast state sample. The highest level of microhardness was achieved for the Sc alloy. 
The results of the TEM EDX analysis of the $\alpha$-Al performed for all alloys are summarized in Figure 8. Like the microhardness, the Mg content in the $\alpha$-Al decreases during the first 20 minutes of the solution treatment. After this, however, the Mg content in the $\alpha$-Al gradually increases to a level of $2.9 \mathrm{wt}$. $\%$ for the Li alloy.

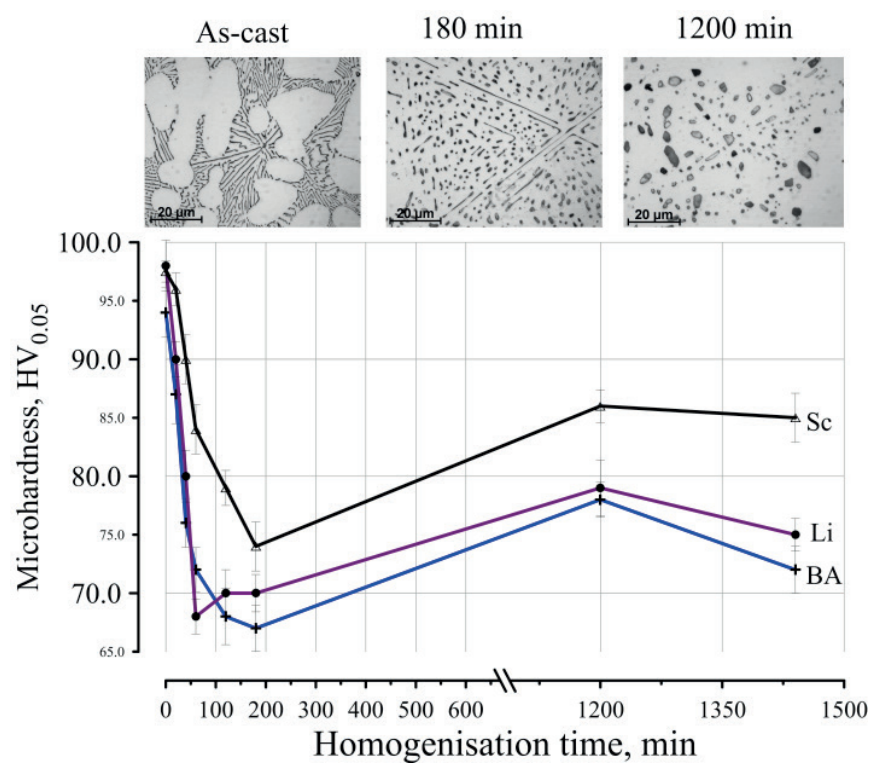

Fig. 7. Changes in microhardness of BA, Li, and Sc alloys during solution treatment

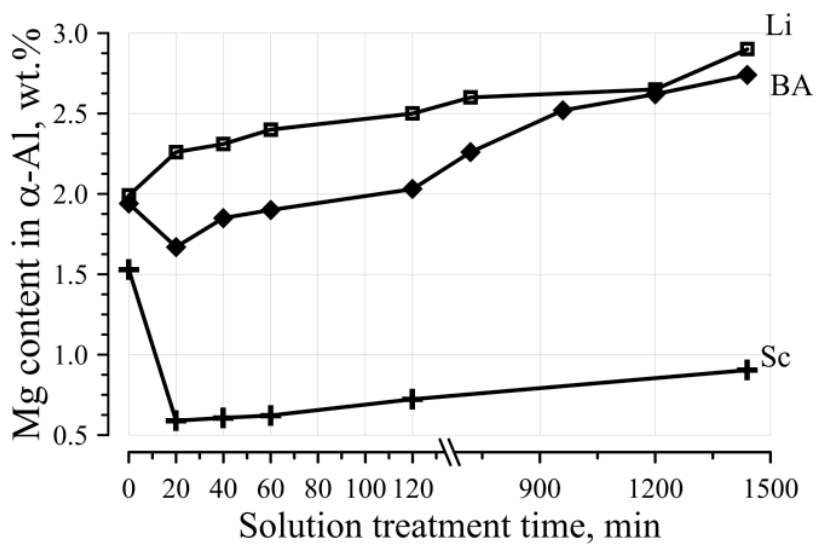

Fig. 8. Changes in Mg content in solid solution during solution treatment of BA, Li, and Sc alloys 
In general, the following facts were observed:

- The $\alpha$-Al contains no precipitates that formed during natural aging (zebra crossing-type precipitates). They were dissolved during the solution treatment. In all specimens, the precipitates were no longer observed after 20 minutes of heating, showing their quick dissolution (see Fig. 9a).

- The TEM investigations confirmed the spheroidization of the $\mathrm{Mg}_{2} \mathrm{Si}$ lamellas. The EDX analysis of the lamellas indicated that no change in the chemical composition of the lamella that takes place during the solution treatment (see insertion in Fig. 7).

- The composition of the $\alpha$-Al solid solution changes during heating (see Fig. 8).

- In the BA, Li, and Sc alloys, a new phase forms during the solution treatment. This phase appeared after 20 minutes of heating (see Fig. 9).

- In the Sc alloy, new precipitates were observed. They formed in the $\alpha$-Al after heating for two hours (see Fig. 9b).

a)

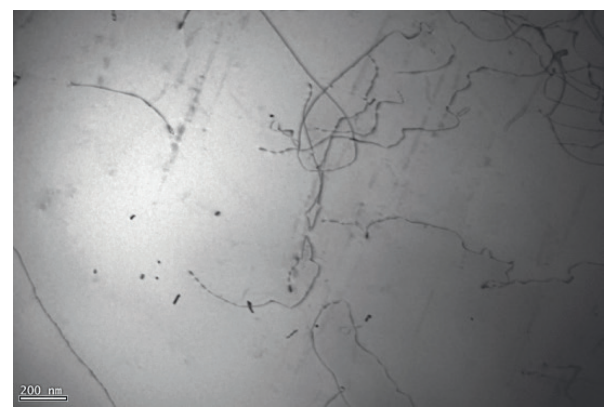

c)

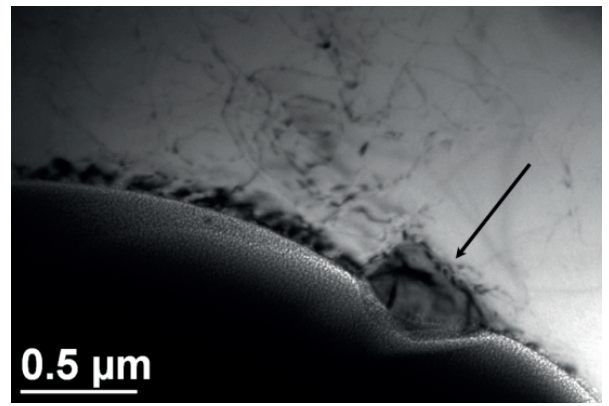

b)

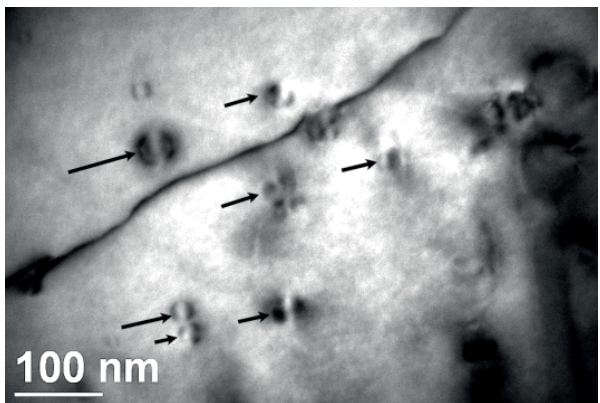

d)

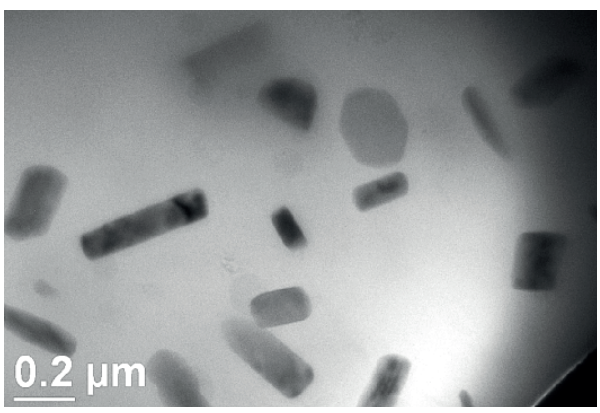

Fig. 9. Microstructural changes observed in alloys during solution treatment: a) bright field image of BA after solution treatment at $575.0^{\circ} \mathrm{C}$ for $20 \mathrm{~min}$; b) bright field image of Sc-containing precipitates formed in Sc alloy during solution treatment at $575.0^{\circ} \mathrm{C}$ for $20 \mathrm{~min}$; c) bright field micrograph of Mn-containing dispersoid nucleated on surface of $\mathrm{Mg}_{2} \mathrm{Si}$ lamella after solution treatment at $575.0^{\circ} \mathrm{C}$ for $20 \mathrm{~min}$; d) bright field micrograph of Mn-containing dispersoids randomly distributed in field of $\alpha-A l$ matrix after solution treatment at $575.0^{\circ} \mathrm{C}$ for $120 \mathrm{~min}$ 
After 20 minutes of heating, new particles were observed adjacent to the $\mathrm{Mg}_{2} \mathrm{Si}$ lamellas in the area of the $\alpha-\mathrm{Al}$ (Figs. 9c and 9d). During heating, the size and volume fraction of these particles becomes larger. Dispersoids (marked by arrows) grow in the interface between the $\mathrm{Mg}_{2} \mathrm{Si}$ and $\alpha$-Al. The dispersoids mainly contain $\mathrm{Mn}, \mathrm{Si}$, and Al. In some cases, small concentrations of $\mathrm{Mg}$ were detected. The measured Fe content was not greater than $0.70 \mathrm{wt} . \%$. The Si content in the dispersoids is $2.30-6.60 \mathrm{wt} . \%$ and does not change during the solution treatment, whereas the $\mathrm{Mn}$ content continuously grows from $21.20 \mathrm{wt} . \%$ after 20 minutes to $33.40 \mathrm{wt} . \%$ after 24 hours of heating. From the composition and morphology, the observed dispersoids were identified again as a secondary $\alpha-\mathrm{Al}(\mathrm{Mn}, \mathrm{Fe})$ Si phase.

The appearance of these dispersoids uncovers the dual importance of $\mathrm{Mn}$ addition for the casting alloys; namely: (i) the change in the morphology of the Fe-rich primary intermetallics formed during solidification; (ii) the reprecipitation of the Mn-rich phase during the solution treatment. The Mn-rich dispersoids act as a strengthening phase for the alloy.

Figure $9 \mathrm{~b}$ illustrates the formation of precipitates in the Sc alloy during the solution treatment soaking at $575.0^{\circ} \mathrm{C}$. After 20 minutes, the decomposition of the $\alpha$-Al has resulted in the formation of precipitates (marked by arrows). The stress field around the particle is visible as two semi-circles. This so-called Ashby-Brown contrast is usual for the TEM observation of small particles and indirectly confirms that they are coherent. Due to the small size of the precipitates, the exact chemical composition could not be measured by EDX analysis (not even when a spot size of $3 \mathrm{~nm}$ was used).

However, it was found that the precipitates are enriched with Sc; hence, they were designated as $\mathrm{Al}_{3} \mathrm{Sc}$ precipitates. After 60 minutes, these regular semicircles still exist; after 120 minutes, they are irregular; and after 1440 minutes, they are strongly distorted. This effect can be interpreted as a transition from coherent to semi-coherent. This means that $\mathrm{Al}_{3} \mathrm{Sc}$ loses its coherency with the $\alpha$-Al matrix after about 120 minutes of heating at $575.0^{\circ} \mathrm{C}$. Further heating results in the growth of the precipitates; after 24 hours, they reach a size of about $100 \mathrm{~nm}$. The obtained results showed that the solution-treatment time should not be longer than 60 minutes for Sc-containing alloys.

\section{Microstructure and phases composition changes during artificial aging}

For the $\mathrm{BA}$ alloy, the $\mathrm{HV}_{0.05}$ significantly rises after 60 minutes of artificial aging and reaches its maximum after 180 minutes (Fig. 10). Further heating cannot significantly improve the microhardness; i.e., the $\mathrm{HV}_{0.05}$ values stay at nearly the same level for up to 24 hours of artificial aging.

In the Li alloy, the $\mathrm{HV}_{0.05}$ was much lower than for the BA alloy. The $\mathrm{HV}_{0.05}$ of the Sc alloy reaches its maximum after 240 minutes of artificial aging (Fig. 10), but the values are still lower than for BA. As was shown earlier, the Mg content in the $\alpha$-Al of the Sc alloy is the lowest one. After a solution treatment at $575.0^{\circ} \mathrm{C}$ for 1 hour, the $\mathrm{Mg}$ content 
in the $\alpha$-Al was about 1.20 wt.\% in Sc, which is dramatically lower than that measured in the BA or Li alloys (where the solid solution contains 2.50 and $3.16 \mathrm{wt} . \% \mathrm{Mg}$, respectively.

It has to be noticed that the most-unfavorable point for the Sc alloy is that the solid solution was already decomposed during the solution treatment, and precipitates were formed (Fig. 9b). It can be expected that not much precipitation will take place during aging (mostly the growth of precipitates). Consequently, the volume fraction of the precipitates should remain constant; only their size should increase.

The TEM examination of the BA alloy showed that, after aging for 180 minutes (where the $\mathrm{HV}_{0.05}$ is maximal), the matrix contains needle-shaped precipitates (which are the $\beta$ "-phase - Fig. 11a). After aging for 90 minutes, only fine black dots are visible. Further aging for 120 minutes results in the precipitation of needles in the $\beta^{\prime \prime}$-phase, which increases in their volume fraction after 600 minutes of aging. The decomposition of the solid solution was proven by TEM EDX measurements in the BA alloy.

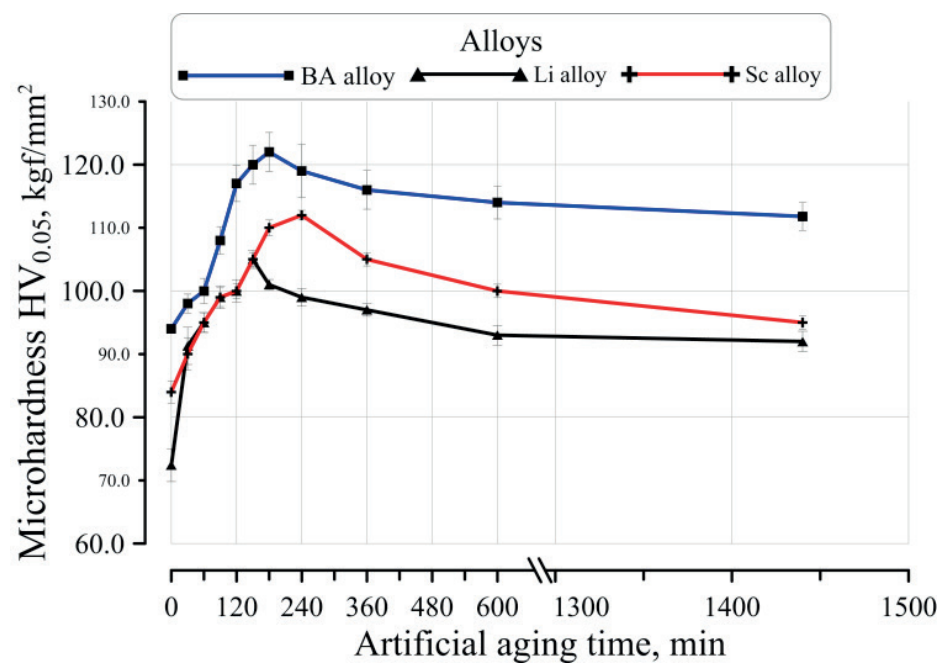

Fig. 10. Microhardness of BA, Li, and Sc as function of artificial aging time

The average composition in the as-quenched condition is $2.00-2.30 \mathrm{wt} . \% \mathrm{Mg}$ and $0.25-0.35 \mathrm{wt} . \% \mathrm{Mn}$. Afteraging for 30 minutes, the Mg content decreases to $1.10-1.20 \mathrm{wt} . \%$, but simultaneous Si intensity appears in the EDX spectrum. Ten measurements of a different $\alpha$-Al give an Si content of about $0.15-0.25 \mathrm{wt} . \%$, which remains unchanged during 24 hours of artificial aging.

The Li alloy showed similar precipitation behavior. After 90 minutes of artificial aging of $\mathrm{Li}$, only dot-like contrasts were detected. After 240 minutes, these dots become somewhat larger; but after 600 minutes (Fig. 11b), the matrix contains precipitates of three types: (i) needle-shaped $\beta^{\prime \prime}$-phase; (ii) cubic-shaped precipitates parallel-oriented to the needles; (iii) small black cubic-shaped precipitates, rotated $45^{\circ}$ from the needles. 
a)

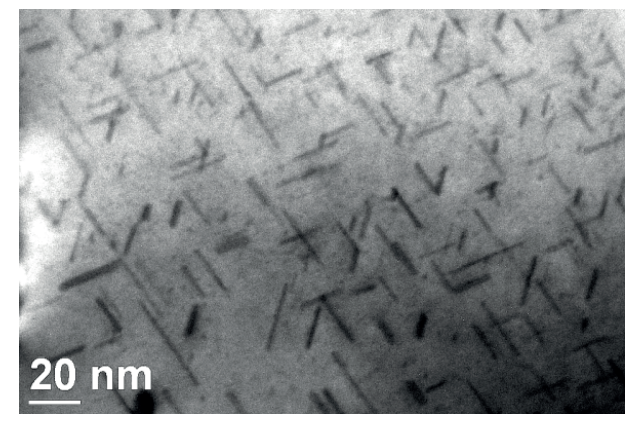

b)

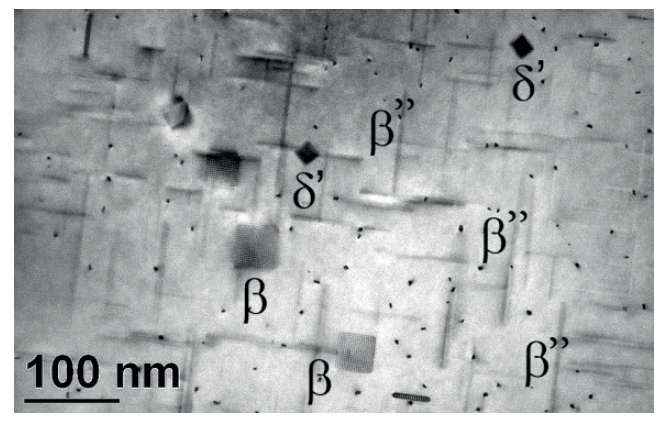

Fig. 11. Bright field images of precipitates observed in BA and Li alloys: a) bright field image of $\beta^{\prime \prime}$ precipitates observed in BA alloy after artificial aging for $180 \mathrm{~min}$; b) bright field image of three types of precipitates observed in Li alloy

From the morphology and composition, the particles of the second type can be identified as equilibrium $\beta-\mathrm{Mg}_{2} \mathrm{Si}$ cuboid particles. The EDX analysis of these particles showed that they are simultaneously enriched by $\mathrm{Mg}$ and $\mathrm{Si}$, which is an additional confirmation that these particles are $\mathrm{Mg}_{2} \mathrm{Si}$.

The third type of precipitate consists of small black cuboids, which are randomly distributed in the $\alpha$-Al. Comparing the TEM image of the Li alloy with literature data about Li-containing alloys [24, 25], the third precipitate can be identified as the $\delta^{\prime} \mathrm{Al}_{3} \mathrm{Li}$ phase (which coexists with two types of $\mathrm{Mg}_{2} \mathrm{Si}$ compounds). A confirmation of the particle composition by EDX measurements is not possible because the light element Li cannot be detected by energy dispersive analysis.

\section{Conclusion}

The obtained results demonstrated that the Al-Mg-Si system can play an integral role in developing a new generation of Al-based casting alloys, which offer promising potential as materials with good strength and ability to be used in as-cast and heat-treated conditions.

1) From the structural point of view, it was established that the structure of Al-Mg-Si casting alloys in the as-cast state consists of three phases; namely, the $\alpha$-Al solid solution, (Al) $+\left(\mathrm{Mg}_{2} \mathrm{Si}\right)$ eutectic, and primary $\mathrm{Mg}_{2} \mathrm{Si}$ crystals. The addition of Mn leads to the formation of the primary $\alpha$-AlFeMnSi phase, which is randomly distributed inside the solid solution grains.

2) From the compositional point of view, EDX measurements of all alloys indicate that, in the as-cast state, the $\alpha$-Al solid solution in the Al-Mg-Si alloys contains about 2.40 at.\% Mg. Si, however, is below the detection limit. The composition of the intermetallics fits well to a stable $\mathrm{Mg}_{2} \mathrm{Si}$ compound. During the solution treatment, 
the $\mathrm{Mg}$ content increases gradually from 2.00 at.\% in the as-cast state to 3.00 at.\% after 24 hours of soaking, producing a super saturation of the $\alpha$-Al. The changes in the Mn content were not monotonous. At the initial stage of the solution treatment, it decreases. Prolonged soaking results in a slight increase in the Mn content; but after 600 minutes of heating, it decreases again. Artificial aging does not show any pronounced changes in the composition of the solid solution nor in the other intermetallics.

3) Regarding the precipitation processes, it was shown that $\mathrm{Mn}$ plays different roles in solidification and solution treatment. During solidification, one part of the Mn atoms dissolves in the $\alpha$-Al matrix; the other part forms primary intermetallics together with $\mathrm{Si}$ and Fe. Solution treatment results in the dissolution of the primary particles and formation of new secondary dispersoids. Their growth starts on the surface of the $\mathrm{Mg}_{2} \mathrm{Si}$ eutectic lamellas. Aging of Al-Mg-Si alloys leads to the formation of needle-shaped precipitates of the $\beta^{\prime \prime}$ - phase in Al-Mg-Si. In Li-containing alloys, two additional types of precipitates were found; namely, the $\mathrm{Mg}_{2} \mathrm{Si} \beta^{\prime \prime}-$ phase (having a plate-like morphology) and $\delta^{\prime}$ phase (small cubic-shaped $\mathrm{Al}_{3}$ Li particles). In Sc-containing alloys, $\mathrm{Al}_{3} \mathrm{Sc}$ precipitates form during the solution treatment; these remain stable during artificial aging.

\section{References}

[1] Ritter F.: Korrosionstabellen metallischer Werkstoffe geordnet nach angreifenden Stollen. Springer-Verlag Wien $\mathrm{GmbH}, 1937$

[2] D'Ans J., Lax E.: Taschenbuch für Chemiker und Physiker. Springer-Verlag Berlin Heidelberg GmbH, 1949

[3] Pirs J., Zalar A.: Investigations of the distribution of elements in phases present in G-AIMg5Si cast alloy with EDX/WDX spectrometers and AES. Microchimica Acta, 101, 1-6 (1990), 295-304

[4] Pirs J.: Distribution of elements in phases present in G-AlMg5Si cast alloy. Aluminium, 69, 5 (1993), 462-465

[5] Aluminium Rheinfelden GmbH brochure, DG-Handbuch 07 (Primary Alloys for Die Casting)

[6] Hielscher U., Sternau H., Koch H., Franke A.J.: Magsimal-59, an AlMgSiMn-type squeeze-casting alloy designed for temper F. Aluminium Rheinfelden $\mathrm{GmbH}$, Rheinfelden, Germany

[7] Jorstad J.L.: Excellent die casting alloy system made better rheocasting. Die Casting Engineer, September 2008, 18-20

[8] Hydro Aluminium Metal Products. TechInfo-Foundry Alloys. New Alloys for High Pressure Die Casting AlMgSiMn

[9] Progress in Aluminium, SAG Aluminium Lend GmbH \& Co KG brochure, 2005

[10] Casting alloys MAXXALLOY ${ }^{\circledR}$ - ULTRA@ GBD-AIMg5Si2MnCr - REAluminium Lend GmbH \& Co KG

[11] Otarwanna S., Gourlay C.M., Laukli H.I., Dahle A.K.: Microstructure Formation in AISi4MgMn and AlMg5Si2Mn High-Pressure Die Castings. Metallurgical and Materials Transactions A, 40 (2009), 1645-1659

[12] Di Sabatino M., Arnberg L., Brusethaug S., Apelian D.: Fluidity evaluation methods for Al-Mg-Si alloys. International Journal of Cast Metals Research, 19, 2 (2006), 94-97

[13] Ji S., Watson D., Fan Z., White M.: Development of a Super Ductile Diecast Al-Mg-Si Alloy. Materials Science \& Engineering A, 556 (2012), 824-833 
[14] Hu Z., Wan L., Lu S., Zhu P., Wu S.: Research on the microstructure, fatigue and corrosion behavior of permanent mold and die cast aluminum alloy. Materials and Design, 55 (2014), 353-360

[15] Petkov T., Künster D., Pabel T., Faerber K., KneißI C., Schumacher P.: Optimierung der Wärmebenhandlung einer AIMgSi-Gusslegierung. Druckguss, 6 (2012), 268-274

[16] Petkov T., Kunstner D., Pabel T., Faerber K., Kneissl C., Schumacher P.: Erweiterung des Eigenschaftspotentials der Legierung AIMg5Si2Mn durch eine gezielte Wärmebehandlung Berg- und Hüttenmännische Monatshefte, X (2013), 1-9, Jvn. Jg. (2013), Heft X@ Springer-Verlag Wien, 1-9

[17] Ji L., Watson D., Fan Z., White M.: Development of a super ductile die cast Al-Mg-Si alloy. Material Science and Engineering A, 556 (2012), 824-833

[18] Eigenfeld K., Franke A., Klan S., Koch H., Lenzcowski B., Pflege B.: New developments in heat resistant aluminum casting materials. Casting Plant and Technology International, 4 (2004), 4-9

[19] Fridlyander J.N., Bratukhin A.G., Davydov V.G.: Soviet Al-Li Alloys of Aerospace Application, Aluminum-lithium. In: Proceedings of the Sixth International Aluminum-Lithium Conference in Garmisch-Partenkirchen, Peters M. and Winkler P.-J. eds., Germany, Vol. 1, 1991, 35-42.

[20] Sauermann R., Friedrich B., Grimmig T., Buenck M., Buhrig-Polaczek A.: Development of Aluminium-Lithium alloys processed by the Rheo Container Process. Solid State Phenomena, 116-117 (2006), 513-517

[21] Barabash O.M., Sulgenko O.V., Legkaya T.N., Korzhova N.P.: Experimental Analysis and Thermodynamic Calculation of the Structural Regularities in the Fusion Diagram of the System of Alloys Al-Mg-Si. Journal of Phase Equilibria, 22, 1 (2001), 5-11

[22] Barabash O.M., Sulzhenko O.V., Legkaya T.N., Korzhova N.P.: Thermodynamic calculation and experimental analysis of the phase diagram of Al-Mg-Si system. Functional Materials, 8, 1 (2001), 154-158

[23] Boyko V., Link T., Korzhova N., Mykhalenkov K.: Microstructure characterization of AlMg5Si2Mn casting alloy. In: Materials Science and Technology (MS\&T) 2013, October 27-31, Montreal, Quebec, Canada, 2013, 1331-1338

[24] Chen R., Huang Z., Chen C.Q., Shen J.Y., Zhang Y.G.: Thermodynamic calculated and TEM observed microstructure of Al-Li-Mg-Si alloys. Materials Science and Engineering A, 280 (2000), 146-150

[25] Murken J., Höhner R., Skrotzki B.: Strain path dependence of the precipitate size evolution of an Al-Mg-Li alloy under combined thermal and mechanical loading. Materials Science and Engineering A, 363 (2003), 159-170 